\title{
PENGARUH APLIKASI EKSTRAK DAUN SIRIH (Piper betle L.) DAN BATANG BROTOWALI (Tinospora sp.) TERHADAP SERANGGA UJI JANGKRIK (Gryllus mitratus) DI LABORATORIUM
}

\section{THE EFFECT OF Piper betle L. AND Tinospora sp. EXTRACT AGAINST Gryllus mitratus IN THE LABORATORY}

\author{
Eko Suroso $^{1 *}$, Lestari Wibowo ${ }^{2}$, Agus M. Hariri ${ }^{2}$ dan Purnomo ${ }^{2}$ \\ ${ }^{1}$ Jurusan Agroteknologi, ${ }^{2}$ Jurusan Proteksi Tanaman, Fakultas Pertanian Universitas Lampung, \\ Bandarlampung, Indonesia \\ Email : ekosuroso1998@gmail.com \\ * Corresponding Author, Diterima: 20 Nov. 2021 , Direvisi: 5 Des. 2021 , Disetujui: 12 Jan. 2022
}

\begin{abstract}
This study aimed to determine the effect of the application of betel leaf extract (Piper betle L.) and brotowali (Tinospora sp.) bark extract on mortality and development of cricket (Gryllus mitratus). The experiment was arranged in completely randomized design (CRD), which consisted of 5 treatments and 5 replications i.e. P0 (control) without the application of botanical insecticide, P1 with 5\% concentration of betel leaf extract application, $P 2$ application of $10 \%$ concentration of betel leaf extract, $P 3$ application of brotowali bark extract with concentration of 5\%, and P4 application of brotowali bark extract with concentration of $10 \%$. The results showed that the application of betel leaf extract with a concentration of $5 \%$ and $10 \%$ caused a cricket mortality of $76 \%$ at 15 days of observation (days after application). While the application of brotowali bark extract with a concentration of $5 \%$ caused a cricket mortality of $86 \%$, and application of $10 \%$ concentration of brotowali stem extract caused mortality of crickets tested insects of $74 \%$ at 15 days of observation. The application of extracts of betel leaf and brotowali bark significantly affected the development of crickets, so that the nymphs that succeeded in becoming imago were not more than $20 \%$.
\end{abstract}

Keywords: Botanical insectiside, Gryllus mitratus, Piper betle L, Tinospora sp.

\begin{abstract}
ABSTRAK
Penelitian ini bertujuan untuk mengetahui pengaruh aplikasi ekstrak daun sirih (Piper betle L.) dan batang brotowali (Tinospora sp.) terhadap mortalitas dan perkembangan serangga uji jangkrik (Gryllus mitratus) di laboratorium. Penelitian disusun dalam rancangan acak lengkap (RAL), yang terdiri dari 5 perlakuan dan 5 ulangan dengan P0 (kontrol) tanpa aplikasi ekstrak pestisida nabati, P1 aplikasi ekstrak daun sirih konsentrasi 5\%, P2 aplikasi ekstrak daun sirih konsentrasi 10\%, P3 aplikasi ekstrak batang brotowali konsentrasi 5\%, dan P4 aplikasi ekstrak batang brotowali konsentrasi $10 \%$. Hasil penelitian menunjukkan bahwa aplikasi ekstrak daun sirih konsentrasi $5 \%$ dan $10 \%$ menyebabkan mortalitas jangkrik sebesar $76 \%$ pada pengamatan 15 hsa (hari setelah aplikasi). Sedangkan aplikasi ekstrak batang brotowali konsentrasi $5 \%$ menyebabkan mortalitas jangkrik sebesar $86 \%$, dan aplikasi ekstrak batang brotowali konsentrasi $10 \%$ menyebabkan mortalitas serangga uji jangkrik sebesar 74\% pada pengamatan $15 \mathrm{hsa}$. Aplikasi ekstrak daun sirih dan batang brotowali secara nyata mempengaruhi perkembangan jangkrik, sehingga nimfa yang berhasil menjadi imago tidak lebih dari $20 \%$.
\end{abstract}

Kata kunci: Batang brotowali, daun sirih, insektisida nabati, jangkrik.

\section{PENDAHULUAN}

Program pengendalian hama terpadu (PHT) dengan mengutamakan pemanfaatan agensi pengendalian hayati atau biopestisida termasuk pestisida nabati sebagai komponen utama dalam sistem PHT yang diatur dalam Peraturan
Pemerintah No. 6 tahun 1995. Dalam mendukung kebijakan tersebut, penggunaan pestisida nabati dalam kegiatan perlindungan tanaman perlu selalu dipromosikan dan disebar luaskan kepada masyarakat umum. Upaya yang dilakukan yaitu dengan menyebarluaskan informasi jenis-jenis tumbuhan yang berpotensi sebagai pestisida 
nabati, yang dapat dimanfaatkan dalam pengendalian hama dan penyakit tanaman (Asmaliyah dkk., 2010).

Menurut Rahayuningtias dan Harijani (2019) Indonesia merupakan negara yang kaya akan keanekaragaman hayati. Kekayaan keanekaragaman hayati yang dimiliki Indonesia diantaranya adalah tanaman rempah dan obat (TRO). TRO mengandung beberapa senyawa aktif yang dapat digunakan untuk bahan baku pembuatan pestisida nabati. Insektisida nabati lebih selektif di alam jika dibandingkan dengan pestisida kimia sintetik, sehingga aman untuk diaplikasikan oleh petani, pengguna, dan juga aman bagi lingkungan sekitar.

Tanaman yang berpotensi untuk digunakan sebagai pestisida nabati antara lain daun sirih (Piper betle L) dan batang brotowali (Tinospora sp.). Kedua jenis tanaman tersebut banyak ditemukan dan telah dikenal oleh masyarakat Indonesia. Pengembangan dan pemanfaatan tanaman sirih dan tanaman brotowali perlu terus diteliti dan dikembangkan.

Tanaman sirih (Piper betle L.) mengandung senyawa aktif berupa minyak atsiri yang dapat digunakan dalam pembuatan pestisida nabati dan pengendalian OPT. Minyak atsiri daun sirih terdiri dari $82,8 \%$ senyawa fenol, dan $17,2 \%$ senyawa non fenol (Koesmiati, 1966 dalam Aisyah dkk., 2008). Minyak atsiri dari daun sirih mengandung senyawa aktif yaitu betle phenol, eugenol, salinen, farnesen, metil eugenol dan germaceren yang dapat digunakan untuk menghambat perkembang-biakan serangga hama (Hidayat dkk., 2015).

Tanaman brotowali (Tinospora sp.) mengandung senyawa aktif yang terdapat pada bagian batang dan akar tanaman. Senyawa aktif yang dimiliki batang dan akar brotowali berupa alkaloid, damar lunak, pati, glikosida, pikroretosid, harsa, zat pahit pikroretin, tinokrisposid, berberin, palmatin, kolumbin dan kaokulin atau pikrotoksi (Yesi dkk., 2019). Untuk mengetahui daya racun pestisida nabati perlu dilakukan pengujian, dalam penelitian ini digunakan serangga uji jangkrik (Gryllus mitratus).

Penelitian ini bertujuan untuk mengetahui pengaruh aplikasi ekstrak daun sirih (Piper betle L.) dan batang brotowali (Tinospora sp.) terhadap mortalitas dan perkembangan serangga uji jangkrik (Gryllus mitratus) di laboratorium

\section{BAHAN DAN METODE}

\subsection{Tempat dan Waktu Penelitian}

Penelitian ini dilaksanakan di Laboratorium Ilmu Hama Tumbuhan, dan Laboratorium Bioteknologi, Fakultas Pertanian, Universitas Lampung. Pelaksanaan penelitian dimulai dari bulan Oktober sampai November 2020.

\subsection{Metode Penelitian}

Penelitian ini disusun dalam rancangan acak lengkap (RAL), yang terdiri dari 5 perlakuan dan 5 ulangan. Lima perlakuan tersebut adalah P0 (tanpa aplikasi (ekstrak pestisida nabati (kontrol)), P1 (aplikasi ekstrak daun sirih konsentrasi 5\%), P2 (aplikasi ekstrak daun sirih konsentrasi 10\%), P3 (aplikasi ekstrak batang brotowali konsentrasi 5\%) dan P4 (aplikasi ekstrak batang brotowali konsentrasi $10 \%$ ). Jumlah satuan percobaan dalam penelitian ini sebanyak 25 satuan percobaan. Pada setiap satuan percobaan digunakan 10 ekor serangga uji jangkrik nimfa instar 4.

\subsection{Pemeliharaan Serangga Uji}

Populasi awal jangkrik diperoleh dari peternak jangkrik di Kecamatan Natar dalam bentuk imago. Selanjutnya jangkrik tersebut dikembangbiakan untuk memperoleh keturunan yang akan digunakan untuk serangga uji. Pemeliharaan imago jangkrik disiapkan dalam sebuah wadah/boks yang berukuran panjang $1 \mathrm{~m}$, lebar $60 \mathrm{~cm}$, dan tinggi 80 $\mathrm{cm}$. Pada boks tersebut diletakkan karton bersusun dan nampan yang berisi pasir dengan ketebalan 2$5 \mathrm{~cm}$. Pasir tersebut merupakan media bagi jangkrik betina untuk bertelur. Pakan imago jangkrik diberikan setiap hari berupa daun kangkung, daun singkong, rumput-rumputan, dan pur (konsentrat pakan ayam).

Apabila jangkrik telah melakukan peneluran pada media pasir, selanjutnya telur tersebut dipisahkan dari media pasir dengan cara melembang. Langkah pertama yaitu menaruh pasir yang telah berisi telur jangkrik ke dalam wadah baskom. Lalu air dituangkan ke dalam baskom secara perlahan sambal dilakukan pengadukan secara hati - hati. Telur jangkrik akan mengambang ke atas permukaan air. Selanjutnya air dituangkan ke dalam sebuah saringan sehingga telur terpisah dari air dan pasir.

Telur jangkrik yang sudah dipisahkan kemudian ditiriskan hingga kering di atas kertas koran. 
Setelah kering, telur jangkrik dibungkus dengan kertas koran dan digantung di ruang yang terhindar dari sinar matahari. Telur jangkrik akan menetas pada 10-12 hari ditandai dengan telurnya berwarna putih susu.

Setelah telur menetas menjadi nimfa selanjutnya dipindahkan ke wadah/boks berukuran panjang $1 \mathrm{~m}$, lebar $60 \mathrm{~cm}$, dan tinggi $80 \mathrm{~cm}$. Wadah/ boks tersebut diletakkan karton bekas telur ayam dan diberikan setiap hari berupa daun kangkung, daun singkong, rumput-rumputan, dan pur (konsentrat pakan ayam). Kemudian dipelihara sampai waktu pengujian yaitu pada saat nimfa jangkrik memasuki instar 4 atau setelah pergantian kulit yang ke 3 .

\subsection{Penyiapan Ekstrak Daun Sirih (Piper betle L.)}

Sebanyak $100 \mathrm{~g}$ daun sirih segar dicuci hingga bersih. Kemudian daun sirih dimasukkan ke dalam blender dan ditambahkan $100 \mathrm{ml}$ air. Setelah diblender sampai halus ditempatkan dalam wadah dan didiamkan selama 24 jam. Selanjutnya, ekstrak tersebut disaring dengan kain kasa dituangkan ke gelas ukur. Dari proses tersebut, diperoleh ekstrak daun sirih sebanyak $100 \mathrm{ml}$. Untuk pembuatan pestisida nabati ekstrak daun sirih dengan konsentrasi 5\% dilakukan dengan cara, mencampurkan $50 \mathrm{ml}$ ekstrak daun sirih dengan 950 $\mathrm{ml}$ air, sehingga diperoleh $1.000 \mathrm{ml}$ pestisida nabati ekstrak daun sirih. Sedangkan untuk membuat pestisida nabati konsentrasi $10 \%$ dilakukan dengan cara mencampurkan $100 \mathrm{ml}$ ekstrak daun sirih ditambahkan $900 \mathrm{ml}$ air sehingga diperoleh 1.000 $\mathrm{ml}$ pestisida nabati ekstrak daun sirih.

\subsection{Penyiapan Ekstrak Batang Brotowali (Tinospora sp.)}

Sebanyak $100 \mathrm{~g}$ batang brotowali yang telah diambil dicuci hingga bersih dan dipotong-potong. Kemudian dimasukkan ke dalam blender dengan ditambahkan $100 \mathrm{ml}$ air. Setelah diblender sampai halus ditempatkan di wadah penampung dan didiamkan selama 24 jam. Selanjutnya ekstrak tersebut di saring dengan kain kasa dituang ke dalam gelas ukur.

Dari proses tersebut, maka diperoleh ekstrak batang brotowali sebanyak $120 \mathrm{ml}$. Untuk pembuatan pestisida nabati ekstrak batang brotowali dengan konsentrasi $5 \%$ dilakukan dengan cara, mencampurkan $50 \mathrm{ml}$ ekstrak batang brotowali dengan $950 \mathrm{ml}$ air, sehingga diperoleh $1.000 \mathrm{ml}$ pestisida nabati ekstrak batang brotowali.
Sedangkan untuk membuat pestisida nabati konsentrasi $10 \%$ dilakukan dengan cara mencampurkan $100 \mathrm{ml}$ ekstrak batang brotewali ditambahkan $900 \mathrm{ml}$ air sehingga diperoleh 1.000 $\mathrm{ml}$ pestisida nabati ekstrak batang brotowali.

\subsection{Aplikasi Ekstrak Daun Sirih dan Batang Brotowali terhadap Serangga Uji Jangkrik}

Aplikasi ekstrak daun sirih dan batang brotowali terhadap serangga uji jangkrik dilakukan di pagi hari. Bahan pestisida nabati yang sudah disiapkan dituangkan ke dalam 5 botol sprayer, setiap botol sprayer berisikan 1 liter ekstrak pestisida nabati dan kontrol (tanpa aplikasi), kemudian diberi label/nama pada masing-masing botol. Ditambahkan perata perekat (Intraside Akarisida $500 \mathrm{ml}$ ) pada setiap botol sprayer konsentrasi $0,2 \mathrm{ml} / \mathrm{l}$. Kemudian diaduk dan dikocok hingga rata, disemprotkan ke dalam toples yang telah diberi pakan dan nimfa jangkrik instar 4. Pemberian dan pergantian pakan jangkrik dilakukan setiap hari.

\subsection{Variabel Pengamatan}

Variabel yang diamati dalam penelitian ini adalah mortalitas dan perkembangan serangga uji. Pengamatan dilakukan satu hari setelah aplikasi (hsa), dan selanjutnya setiap hari selama 24-30 hari, sampai terbentuk atau hingga semua serangga uji mati. Pengamatan dan pengumpulan data dilakukan dengan menghitung tingkat kematian (mortalitas) nimfa jangkrik dengan rumus :

$$
\text { Mortalitas }=\frac{A}{B} \times 100 \%
$$

Keterangan : $A=$ Jumlah nimfa jangkrik mati dan $\mathrm{B}=$ Jumlah nimfa jangkrik pada satu satuan percobaan.

\subsection{Analisis Data}

Homogenitas ragam data di uji dengan uji Bartlett. Apabila hasilnya homogen dilanjutkan dengan analisis ragam. Kemudian dilakukan pengujian nilai tengah dengan Uji BNT (Beda Nyata Terkecil) pada taraf 5\%.

\section{HASIL DAN PEMBAHASAN}

\subsection{Hasil penelitian}

Aplikasi insektisida nabati ekstrak daun sirih (Piper betle L.) dan batang brotowali (Tinospora sp.) 
terhadap serangga uji jangkrik (Gryllus mitratus) tampak nyata berpengaruh terhadap mortalitas dan perkembangan hidup jangkrik. Mortalitas serangga uji terjadi sejak 3 hsa (hari setelah aplikasi). Insektisida nabati ekstrak daun sirih dan batang brotowali secara nyata mampu menghambat perkembangan serangga uji jangkrik dalam hal ukuran imago yang terbentuk dan jumah imago yang terbentuk.

\subsubsection{Mortalitas jangkrik}

Sejak pengamatan 3 hsa, persentase mortalitas terus meningkat hingga 15 hsa. Pada pengamatan hari ke 15 setelah aplikasi, mortalitas serangga uji jangkrik pada semua perlakuan aplikasi pestisida nabati ekstrak daun sirih dan batang brotowali secara nyata berbeda dengan perlakuan kontrol. Mortalitas jangkrik pada perlakuan aplikasi ekstrak daun sirih tidak berbeda nyata dengan perlakuan aplikasi ekstrak batang brotowali. Begitu juga pada perlakuan aplikasi pestisida nabati ekstrak daun sirih dan batang brotowali pada taraf konsentrasi $5 \%$ dan $10 \%$ tidak berbeda nyata. Mortalitas serangga uji jangkrik akibat perlakuan pestisida nabati daun sirih dan batang brotowali cukup tinggi yaitu berkisar antara $74-86 \%$ (Tabel 1).

\subsubsection{Perkembangan serangga uji jangkrik}

Aplikasi ekstrak daun sirih dan batang brotowali juga nyata mempengaruhi persentase nimfa jangkrik yang berhasil menjadi imago. Pada perlakuan kontrol, serangga uji yang berhasil menjadi imago sebesar $80 \%$. Sedangkan pada seluruh perlakuan aplikasi ekstrak daun sirih dan batang brotowali serangga uji yang berhasil menjadi imago tidak lebih dari $20 \%$ dan tidak berbeda nyata kecuali dengan perlakuan pada kontrol (Tabel 2). Nimfa instar 4 jangkrik sebelum berhasil menjadi imago, mengalami 2 kali pergantian kulit (molting). Nimfa instar 4 jangkrik yang berhasil menjadi imago memerlukan waktu sampai 13 hsa, ditandai dengan terbentuknya dua pasang sayap dan pertumbuhan ukuran tubuh jangkrik.

Aplikasi ekstrak daun sirih dan batang brotowali secara nyata mempengaruhi perkembangan ukuran tubuh jangkrik. Ukuran panjang tubuh jangkrik pada perlakuan batang brotowali 5\% (P3) yaitu 21,8 mm dan secara nyata berbeda pada perlakuan kontrol $(\mathrm{P} 0)$, namun tidak berbeda nyata dengan perakuan yang lain. Ukuran lebar tubuh jangkrik pada perlakuan daun sirih $10 \%(\mathrm{P} 2)$ adalah 7,2 mm dan secara nyata berbeda pada perlakuan kontrol (P0), namun tidak berbeda nyata dengan perakuan yang lain (Tabel 3).

\subsection{Pembahasan}

Hasil analisis ragam menunjukkan bahwa akibat perlakuan pemberian pestisida nabati ekstrak daun sirih dan batang brotowali terhadap serangga uji jangkrik mampu meningkatkan persentase mortalitas jangkrik sejak 3 hsa hingga 15 hsa. Dari Tabel 1 terlihat bahwa pestisida nabati ekstrak daun sirih dan batang brotowali cukup efektif untuk digunakan karena mampu menyebabkan mortalitas serangga uji lebih dari 70\%. Sedangkan untuk perkembangan jangkrik Tabel 2 dapat dikatakan efektif karena pada semua perlakuan aplikasi ekstrak daun sirih 5\% dan $10 \%$ serangga uji jangkrik yang berhasil menjadi imago tidak lebih dari 20\%. Dan perlakuan pada batang brotowali $5 \%$ dan $10 \%$ serangga uji jangkrik yang berhasil menjadi imago tidak lebih dari $20 \%$.

Tabel 1. Persentase Mortalitas Jangkrik Akibat Perlakuan Pestisida Nabati Ekstrak Daun Sirih dan Batang Brotowali.

\begin{tabular}{cccccc}
\hline \multirow{2}{*}{ Perlakuan } & \multicolumn{5}{c}{ Mortalitas jangkrik (\%) } \\
\cline { 2 - 6 } & $3 \mathrm{hsa}$ & $6 \mathrm{hsa}$ & $9 \mathrm{hsa}$ & $12 \mathrm{hsa}$ & 15 hsa \\
\hline P0 & $4 \mathrm{~b}$ & $8 \mathrm{c}$ & $8 \mathrm{~b}$ & $10 \mathrm{c}$ & $14 \mathrm{~b}$ \\
P1 & $24 \mathrm{a}$ & $46 \mathrm{a}$ & $62 \mathrm{a}$ & $74 \mathrm{a}$ & $76 \mathrm{a}$ \\
P2 & $22 \mathrm{a}$ & $38 \mathrm{ab}$ & $58 \mathrm{a}$ & $70 \mathrm{ab}$ & $76 \mathrm{a}$ \\
P3 & $18 \mathrm{a}$ & $30 \mathrm{~b}$ & $60 \mathrm{a}$ & $76 \mathrm{ab}$ & $86 \mathrm{a}$ \\
P4 & $12 \mathrm{ab}$ & $40 \mathrm{ab}$ & $58 \mathrm{a}$ & $64 \mathrm{~b}$ & $74 \mathrm{a}$ \\
\hline F Hitung & $2,54^{*}$ & $15,67^{*}$ & $22,03^{*}$ & $57,97^{*}$ & $42,7^{*}$ \\
\hline F Tabel & 0,08 & 2,13 & 2,13 & 2,13 & 2,13 \\
\hline
\end{tabular}

Keterangan : $\mathrm{P} 0$ = tanpa aplikasi ekstrak pestisida nabati (kontrol), $\mathrm{P} 1=$ aplikasi ekstrak daun sirih ekstrak daun sirih konsentrasi 10\%, P2 = aplikasi batang brotowali konsentrasi 10\%, P3 = aplikasi ekstrak batang brotowali konsentrasi 5\% dan P4 = aplikasi ekstrak konsentrasi 5\%. Angka dalam kolom yang diikuti huruf yang sama tidak berbeda nyata menurut uji BNT 5\%. 
Tabel 2. Persentase Nimfa Jangkrik yang Berhasil Menjadi Imago pada Perlakuan Aplikasi Pestisida Nabati Ekstrak Daun Sirih dan Batang Brotowali.

\begin{tabular}{clc}
\hline Kode & \multicolumn{1}{c}{ Perlakuan } & Imago terbentuk (\%) \\
\hline P0 & Kontrol & $80 \mathrm{a}$ \\
P1 & Aplikasi ekstrak daun sirih 5\% & $16 \mathrm{~b}$ \\
P2 & Aplikasi ekstrak daun sirih 10\% & $20 \mathrm{~b}$ \\
P3 & Aplikasi ekstrak batang brotowali 5\% & $18 \mathrm{~b}$ \\
P4 & Aplikasi ekstrak batang brotowali 10\% & $20 \mathrm{~b}$ \\
\hline F Hitung & & $17,62 *$ \\
\hline F Tabel & & 2,13 \\
\hline
\end{tabular}

Keterangan : Angka dalam kolom yang diikuti huruf yang sama tidak berbeda nyata menurut uji BNT 5\%.

Tabel 3. Panjang dan Lebar Tubuh Imago Jangkrik pada Perlakuan Pestisida Nabati Ekstrak Daun Sirih dan Batang Brotowali.

\begin{tabular}{clcc}
\hline \multirow{2}{*}{ Kode } & \multicolumn{1}{c}{ Perlakuan } & \multicolumn{2}{c}{ Ukuran (mm) } \\
\cline { 3 - 4 } & Kontrol & Panjang & Lebar \\
\hline P0 & Aplikasi ekstrak daun sirih 5\% & 23,4 a & 8,2 \\
P1 & Aplikasi ekstrak daun sirih 10\% & 22,6 ab & 7,8 ab \\
P2 & Aplikasi ekstrak batang brotowali 5\% & 23,0 ab & 7,2 b \\
P3 & Aplikasi ekstrak batang brotowali 10\% & $21,8 \mathrm{~b}$ & 7,4 ab \\
P4 & & 22,8 ab & 7,4 ab \\
\hline F Hitung & & $1,93 *$ & $2 *$ \\
\hline F Tabel & & 0,15 & 0,14 \\
\hline
\end{tabular}

Keterangan : Angka dalam kolom yang diikuti huruf yang sama tidak berbeda nyata menurut uji BNT 5\%.

Perlakuan aplikasi pestisida nabati ekstrak daun sirih (Piper betle L.) terhadap serangga uji jangkrik (Gryllus mitratus) memiliki pengaruh secara nyata atau lebih baik dari perlakuan kontrol dalam meningkatkan angka kematian jangkrik. Hal ini didukung Sastrodihardjo (1999) dalam penelitian Yunianti (2016) bahwa senyawa aktif yang terdapat dalam pestisida nabati dapat masuk melalui sistem pernafasan baik berupa gas/udara yang masuk melalui stigma yang menuju ke saluran trakea dan akhirnya akan masuk kedalam jaringan yang menyebabkan kematian serangga.

Menurut penelitian Anisah dan Sukesi (2018) bahwa pada daun sirih terdapat kandungan senyawa eugenol dan kavikol yang dapat memberikan efek kematian pada larva lalat rumah (Musca domestica) sebagai hewan uji, dengan konsentrasi $0,4827 \%$ ekstrak daun sirih mampu membunuh larva lalat rumah (M. domestica) sebesar $50 \%$. Hal tersebut didukung oleh pernyataan Wahyuni dan Loren (2015) di dalam penelitian membuktikan bahwa ekstrak daun sirih bersifat toksik (racun) dan ekstrak daun sirih membutuhkan konsentrasi tinggi untuk meningkatkan mortalitas larva nyamuk Aedes aegypti.

Perlakuan pemberian pestisida nabati ekstrak batang brotowali (Tinospora sp.) terhadap serangga uji jangkrik (Gryllus mitratus) memiliki pengaruh secara nyata atau lebih baik dari perlakuan kontrol dalam meningkatkan angka kematian jangkrik. Hal ini didukung dengan penelitian Safitri (2018) yang menyatakan pemberian ekstrak batang brotowali mampu menunjukkan pengaruh yang berbeda terhadap mortalitas larva ulat krop (Crocidolomia pavonana). Apabila konsentrasi ekstrak batang brotowali bertambah, maka tingkat mortalitas ulat krop (C. pavonana) juga mengalami peningkatan.

Menurut penelitian Yesi dkk (2019) pemberian ekstrak batang brotowali dosis $20 \%$ mampu menekan angka mortalitas hama kutu daun (Aphis gossypii) jauh lebih tinggi(dengan nilai mortalitas mencapai 100\%). Semakin besar konsentrasi ekstrak batang brotowali maka semakin besar juga tingkat mortalitas ulat krop (Crocidolomia pavonana).

\section{KESIMPULAN}

Aplikasi ekstrak daun sirih konsentrasi 5\% menyebabkan mortalitas serangga uji jangkrik sebesar $76 \%$ dan ekstrak daun sirih konsentrasi $10 \%$ menyebabkan mortalitas serangga uji jangkrik sebesar $76 \%$. pada pengamatan $15 \mathrm{hsa}$. Sedangkan aplikasi ekstrak batang brotowali 
konsentrasi $5 \%$ menyebabkan mortalitas serangga uji jangkrik sebesar $86 \%$, dan ekstrak batang brotowali konsentrasi $10 \%$ menyebabkan mortalitas serangga uji jangkrik sebesar $86 \%$ pada pengamatan 15 hsa. Aplikasi ekstrak daun sirih dan batang brotowali juga nyata menghambat perkembangan serangga uji jangkrik, sehingga nimfa yang berhasil menjadi imago tidak lebih dari $20 \%$.

\section{DAFTAR PUSTAKA}

Aisyah, S., Darma, T.I.G.K., dan Anggraeni, I. 2008. Pengujian Aktivitas Ekstrak (Piper betle Linn) terhadap Pythium sp. pada Persemaian Pinus (Pinus merkusii Jungh et de Vriese) secara In-Vitro. Jurnal Penelitian Hutan Tanaman. 5 (2) : 119-138.

Anisah dan Sukesi, T.W. 2018. Uji Efektifitas Ekstrak Daun Sirih (Piper betle L.) sebagai Larvasida Larva Lalat Rumah (Musca domestica) Jurnal Vektor Penyakit. 12 (1) :39-45.

Asmaliyah, Wati, E.E.H., Utami, S., Mulyadi, K., Yudhistira, dan Sari, F.W. 2010. Pengenalan Tumbuhan Penghasil Pestisida Nabati dan Pemanfaatannya Secara Tradisional. Kementerian Kehutanan Badan Penelitian dan Pengembangan Kehutanan Pusat Penelitian dan Pengembangan Produktivitas Hutan. Jakarta. 58 hlm.

Hidayat, T., Supriyadi, dan Sarjiyah. 2015. Pengaruh Pemberian Ekstrak Daun Sirih (Piper betle L.) untuk Mengendalikan Damping-Off pada Tanaman Cabai (Capsicum annum). Planta Tropika Journal of Agro Science. 3 (1) : 61-66.
Rahayuningtias, S. dan Harijani,W.S. 2019. Kemampuan Pestisida Nabati (Mimba, Gadung, Laos dan Serai), terhadap Hama Tanaman Kubis (Brassica oleracea L.). Jurnal Ilmu-Ilmu Pertanian. 15 (1) : 207211.

Safitri, Y. 2018. Pengaruh Campuran Ekstrak Batang Brotowali dan Rimpang Kunyit terhadap Mortalitas dan Aktivitas Makan Ulat Krop (Crocidolomia pavonana F.) Pada Tanaman Sawi Caisim (Brassica juncea L.). (Skripsi). Fakultas Tarbiah dan Keguruan. Universitas Islam Negeri. Lampung. $74 \mathrm{hlm}$.

Yesi, Zen, S., dan Achyani. 2019. Pengaruh Variasi Dosis Ekstrak Batang Brotowali (Tinospora crispa L.) terhadap Mortalitas Hama Kutu Daun (Aphis gossypii L.) Tanaman Mentimun (Cucumis sativus L.) Sebagai Sumber Belajar Biologi. Jurnal Pendidikan Biologi. 10 (2) : 162-170.

Yunianti, L. 2016. Uji Efektifitas Ekstrak Daun Sirih (Piper betle L.) Sebagai Insektisida Alami terhadap Mortalitas Walang Sangit (Leptocorisa acuta). (Skripsi). Fakultas Keguruan dan Ilmu Pendidikan. Universitas Sanata Dharma. Yogyakarta. $112 \mathrm{hlm}$.

Wahyuni, D. dan Loren, I. 2015. Perbedaan Toksisitas Ekstrak Daun Sirih (Piper betle L.) dengan Ekstrak Biji Srikaya (Annona squamosa L.) terhadap Larva Nyamuk Aedes aegypti L. Saintifika. 17 : 38-48. 